\title{
Impact of Online Classes on the Health of Indian Medical and Dental Students during the Pandemic Period of COVID-19: An Observational Study
}

\author{
Alok Tripathi $^{1} \quad$ Ajay Kumar Patel $^{2}$ Ishi Jain ${ }^{3}$ Satyam Khare ${ }^{3}$ Shilpi Jain ${ }^{3}$ Shobhit Raizaday ${ }^{3}$
}

${ }^{1}$ Department of Anatomy, Subharti Medical College, Swami Vivekanand Subharti University, Meerut, Uttar Pradesh, India

${ }^{2}$ Department of Anatomy, All India Institute of Medical Sciences, Deoghar, Jharkhand, India

${ }^{3}$ Department of Anatomy, Subharti Medical College, Swami Vivekanand Subharti University, Meerut, Uttar Pradesh, India

Int J Recent Surg Med Sci 2022;8:109-113.

\author{
Address for correspondence Dr. Ishi Jain, MBBS, Department of \\ Anatomy, Subharti Medical College, Swami Vivekanand Subharti \\ University, Meerut, Uttar Pradesh, India \\ (e-mail: jain.ishi17@gmail.com).
}

\begin{abstract}
Keywords

- COVID-19

- health

- lockdown

- online teaching

- students

Background After attending online classes during the coronavirus disease pandemic, drastic changes were observed in their physical, mental, and social health, which were also reflected in their academic performances. All these negative impacts were due to prolonged screen time and sedentary lifestyle due to online classes, no interaction with classmates, and poor teacher-student interaction.

Material and Method This was an observational study, and the data were collected through a self-designed questionnaire sent via the mode of electronic message (Google forms) to Indian medical and dental students across India. Eight hundred students responded to our questionnaire. All the responses were then compiled in the form of adequate tables and charts to study the responses.

Results Among 800 responders, $83.4 \%$ students preferred the offline mode of teaching over the online mode. Online classes had negative impact on the academic performance of $73.6 \%$ students and $67 \%$ students were frustrated with their academic performance. Weight gain due to lockdown (online classes) was seen in $62.6 \%$ students. The low energy level was seen in $58.8 \%$ students. Lost interest toward careers was observed in $51.6 \%$ students. Complains of frequent headaches were seen in $50.6 \%$ students, and $54.3 \%$ students had visual problems. Interaction with batch mates during classes was missed by $76.1 \%$ students.

Conclusion From the present study, we conclude that there is a negative impact of online classes not only on the physical, mental, and social health but also on the academic performance and interest toward the careers of Indian medical and dental students.
\end{abstract}

received

November 16, 2021

accepted

December 15, 2021
DOI https://doi.org/ 10.1055/s-0042-1742630. ISSN $2455-7420$.
(C) 2022. Medical and Surgical Update Society. All rights reserved. This is an open access article published by Thieme under the terms of the Creative Commons Attribution-NonDerivative-NonCommercial-License, permitting copying and reproduction so long as the original work is given appropriate credit. Contents may not be used for commercial purposes, or adapted, remixed, transformed or built upon. (https://creativecommons.org/ licenses/by-nc-nd/4.0/)

Thieme Medical and Scientific Publishers Pvt. Ltd., A-12, 2nd Floor, Sector 2, Noida-201301 UP, India 


\section{Introduction}

With the outbreak of the coronavirus disease 2019 (COVID19) pandemic, a drastic change in the education system has been observed, mainly in medical and dental branches. All universities have moved toward online teaching, suspending the offline classes in a span of few days. ${ }^{1}$ This transition was a necessity for the education system during such a contagious situation. But every change comes with its own pitfalls. On the one hand, online teaching is helping to continue the education without putting students at the risk of catching the virus, and, on the other hand, this method is slowly and progressively making students prone to depression and many other health problems. The major drawback of online teaching and learning is limited nonverbal communication. ${ }^{2}$ Stated as the definition on the health by World Health Organization "it is a state of complete physical, mental and social wellbeing and not merely an absence of disease and infirmity", ${ }^{3}$ all three aspects of health are affected in online classes. At present, medical students are exposed to fully online teaching modules, textbooks, video lectures, and online computer-based theory exams and viva. ${ }^{4,5}$ Students are suffering from frequent headaches and visual disturbances due to increased screen time. Due to online classes, there is a shift toward a sedentary lifestyle because of prolonged sitting and this shift is leading to weight gain which is a risk factor for many diseases. Menstrual irregularities are also seen due to sedentary lifestyle, stress, and weight gain. Looking toward mental and social aspects of health, students are unknowingly going toward depression. The reason for such lockdown-based depression is the lack of social interaction with peer groups which is, in turn, leading to frustrated and aggressive nature. To combat their social isolation, students have started deviating toward addiction, incidences of smoking and drinking are increasing majorly due to loneliness and pressure of studies. All these factors are influencing the academic performance of students. Since childhood students are prepared and studying via the offline pattern of teaching. Due to lockdown when suddenly the teaching pattern shifted toward the online pattern of teaching, students were not able to adapt to this pattern and lack of concentration and poor performance were observed. This poor performance again results in frustrated and aggressive nature. This frustration also affects the relationship of students with their parents. This online teaching pattern has a more aggressive effect on medical and dental students because both of these branches demand clinical exposure which cannot be provided via online teaching. In both these branches, students should be able to interact with their subject (cadaver or patient) physically. Virtual interaction with the subject is not a substitute for physical interaction. Secondly, in both these branches, interactive teaching plays a very important role which is lacking due to the online pattern. It is difficult both for students and teachers to understand the concept and to educate the students. In long term, this online teaching pattern will have a negative impact not merely on the health but also on the careers of the students.

\section{Aims and Objectives}

This study was conducted to the evaluate impact of online teaching on physical, mental, and social aspects of the health of Indian medical and dental students during the period of COVID-19 pandemic. Knowledge about the impact of online classes is important for both teachers and students, because if any subsequent pandemic wave strikes, students should be mentally prepared to continue their studies via the online teaching mode with minimal effect on their health and teachers should be ready to educate students via the online teaching mode with maximum understanding.

\section{Material and Methods}

Before starting the study, approval from the Institutional Ethical Committee of Subharti Medical College, Meerut, in accordance with the Helsinki Declaration of 1975 revised in 2000 , was taken. It was an observational study conducted from 25th July 2021 to 25th September 2021 (2 months duration). Data were collected using an online self-administered questionnaire sent via the mode of electronic messages (Google forms) to medical and dental students across India. Students willing to participate filled the form without any compulsion. The sample size consisted of 800 individuals who responded adequately. The sampling type was simple purposive. The responses were then compiled and computed in the form of tables and figures.

\section{Statistical Analysis}

All statistical analyses were carried out through statistical software SPSS version 25.0. All the graphs and tables were compiled using Microsoft Excel.

\section{Result}

- Table 1 shows the compilation of all the responses collected during the study. In the 800 collected responses of Indian medical and dental students, 470 (58.8\%) were females and $330(41.3 \%)$ were males. In the study population, $682(85.3 \%)$ students had siblings while 118 (14.7\%) were single child. Parents of 121 (15.1\%) students were doctor, whereas the occupation of parents of 679 (84.9\%) students was other than a doctor. Out of 800, only 133 (16.6\%) students preferred the online mode of teaching and the rest of 667 (83.4\%) students preferred the offline mode. Of 800 students, $589(73.6 \%)$ had a bad impact of online teaching on their academic performance while 211 (26.4\%) had a good impact of online teaching on their academic performance. In the study, it was found that $360(45 \%)$ students felt lonely during the lockdown (online classes) while 440 (55\%) students did not feel any loneliness. Disturbance in the sleep cycle during lockdown (online classes) was observed in 386 (48.3\%) students, while 414 (51.7\%) students did not experience any sleep disturbance. Weight gain was observed in 501 (62.6\%) students, and 
Table 1 Changes seen in male and female medical and dental students during lockdown

\begin{tabular}{|c|c|c|c|c|}
\hline \multicolumn{2}{|c|}{$\begin{array}{l}\text { Changes during lockdown } \\
\text { (COVID-19 pandemic) }\end{array}$} & \multicolumn{2}{|c|}{$\begin{array}{l}\text { Gender (abso- } \\
\text { lute number) }\end{array}$} & \multirow{3}{*}{$\begin{array}{l}\text { Total } \\
\text { frequency }\end{array}$} \\
\hline & & \multirow{2}{*}{$\begin{array}{l}\text { Male } \\
262\end{array}$} & \multirow{2}{*}{$\begin{array}{l}\text { Female } \\
420\end{array}$} & \\
\hline Do you have & Yes & & & \\
\hline & No & 68 & 50 & 118 \\
\hline & Total & 330 & 470 & 800 \\
\hline \multirow{3}{*}{$\begin{array}{l}\text { Occupation of } \\
\text { parents }\end{array}$} & Doctor & 58 & 63 & 121 \\
\hline & Other & 272 & 407 & 679 \\
\hline & Total & 330 & 470 & 800 \\
\hline \multirow{3}{*}{$\begin{array}{l}\text { Preferred mode of } \\
\text { teaching as a } \\
\text { student }\end{array}$} & Offline & 270 & 397 & 667 \\
\hline & Online & 60 & 73 & 133 \\
\hline & Total & 330 & 470 & 800 \\
\hline \multirow{3}{*}{$\begin{array}{l}\text { Impact of online } \\
\text { teaching on online } \\
\text { classes }\end{array}$} & Good & 77 & 134 & 211 \\
\hline & Bad & 253 & 336 & 589 \\
\hline & Total & 330 & 470 & 800 \\
\hline \multirow{3}{*}{$\begin{array}{l}\text { Feel lonely during } \\
\text { lockdown }\end{array}$} & Yes & 165 & 195 & 360 \\
\hline & No & 165 & 275 & 440 \\
\hline & Total & 330 & 470 & 800 \\
\hline \multirow{3}{*}{$\begin{array}{l}\text { Disturbance in the } \\
\text { sleep cycle }\end{array}$} & Yes & 145 & 241 & 386 \\
\hline & No & 185 & 229 & 414 \\
\hline & Total & 330 & 470 & 800 \\
\hline \multirow[t]{3}{*}{ Weight gain } & Yes & 208 & 293 & 501 \\
\hline & No & 122 & 177 & 299 \\
\hline & Total & 330 & 470 & 800 \\
\hline \multirow{3}{*}{$\begin{array}{l}\text { Frustrated with } \\
\text { academic } \\
\text { performance }\end{array}$} & Yes & 229 & 307 & 536 \\
\hline & No & 101 & 163 & 264 \\
\hline & Total & 330 & 470 & 800 \\
\hline \multirow{3}{*}{$\begin{array}{l}\text { Deviated toward } \\
\text { addiction }\end{array}$} & Yes & 114 & 104 & 218 \\
\hline & No & 216 & 366 & 582 \\
\hline & Total & 330 & 470 & 800 \\
\hline \multirow{3}{*}{$\begin{array}{l}\text { Feeling low in } \\
\text { energy }\end{array}$} & Yes & 180 & 290 & 470 \\
\hline & No & 150 & 180 & 330 \\
\hline & Total & 330 & 470 & 800 \\
\hline \multirow{3}{*}{$\begin{array}{l}\text { Lost interest in } \\
\text { careers }\end{array}$} & Yes & 179 & 234 & 413 \\
\hline & No & 151 & 236 & 387 \\
\hline & Total & 330 & 470 & 800 \\
\hline \multirow[t]{3}{*}{ Frequent headaches } & Yes & 133 & 272 & 405 \\
\hline & No & 197 & 198 & 395 \\
\hline & Total & 330 & 470 & 800 \\
\hline \multirow[t]{3}{*}{ Visual problem } & Yes & 155 & 279 & 434 \\
\hline & No & 175 & 191 & 366 \\
\hline & Total & 330 & 470 & 800 \\
\hline \multirow{3}{*}{$\begin{array}{l}\text { Prepared for online } \\
\text { classes if another } \\
\text { pandemic wave } \\
\text { strikes }\end{array}$} & Yes & 198 & 271 & 469 \\
\hline & No & 132 & 199 & 331 \\
\hline & Total & 330 & 470 & 800 \\
\hline
\end{tabular}

(Continued)
Table 1 (Continued)

\begin{tabular}{|l|l|l|l|l|}
\hline \multicolumn{2}{|l|}{$\begin{array}{l}\text { Changes during lockdown } \\
\text { (COVID-19 pandemic) }\end{array}$} & \multicolumn{2}{|l|}{$\begin{array}{l}\text { Gender (abso- } \\
\text { lute number) }\end{array}$} & $\begin{array}{l}\text { Total } \\
\text { frequency }\end{array}$ \\
\cline { 3 - 5 } & Male & Female & \\
\hline \multirow{2}{*}{$\begin{array}{l}\text { Relationship with } \\
\text { parents }\end{array}$} & Good & 278 & 409 & 687 \\
\cline { 2 - 5 } & Bad & 52 & 61 & 113 \\
\cline { 2 - 5 } & Total & 330 & 470 & 800 \\
\hline \multirow{2}{*}{$\begin{array}{l}\text { Miss interaction } \\
\text { with batch mates }\end{array}$} & Yes & 249 & 360 & 609 \\
\cline { 2 - 5 } & No & 81 & 110 & 191 \\
\cline { 2 - 5 } & Total & 330 & 470 & 800 \\
\hline
\end{tabular}

Abbreviation: COVID-19, coronavirus disease 2019.

there was no weight gain in 299 (37.4\%) students during lockdown (online classes). According to the collected data, 536 (67\%) students were frustrated with their academic performance during online teaching and only 264 (33\%) students were not frustrated with their academic performance. During the lockdown, 218 (27.3\%) students were deviated toward addiction and no such deviation was seen in $582(72.8 \%)$ students. In the study population, 470 (58.8\%) students felt lethargic during lockdown (online classes) and the rest of the 330 (41.3\%) students did not feel lethargic. During online classes, 413 (51.6\%) students lost interest in their careers, while 387 (48.4\%) students did not lose interest in their careers. During online classes, 405 (50.6\%) students experienced frequent headaches and 434 (54.3\%) students had visual problems. In case another pandemic wave strikes, 486 (58.6\%) students were mentally prepared for online classes while 331 (41.4\%) students were still not mentally prepared for online classes. During lockdown, 687 (85.9\%) students had a good relationship with their parents while the relationship of only $113(14.1 \%)$ students was affected with parents. During lockdown (online classes), 609 (76.1\%) students missed the interaction with their batch mates and only 191 (23.9\%) students did not miss the interaction with their batch mates. Out of 470 female students, 141 (30\%) faced menstrual irregularities during online classes due to the COVID-19 pandemic and $329(70 \%)$ female students did not face any menstrual irregularities (-Fig. 1). Out of 330 male students, 118 (36\%) male students experienced aggressive behavior during online classes due to the COVID-19 pandemic and 212 (64\%) male students did not experience any such aggressive behavior (-Fig. 2). Out of 218 students who were deviated to addiction, 66 (30.3\%) deviated toward alcohol drinking and 67 (30.7\%) toward cigarette smoking (-Figs. 3 and 4).

\section{Discussion}

In our study, $58.8 \%$ students were females and $41.3 \%$ were males. According to our study, the preferred mode of teaching was offline (83.4\%) which was similar to the study conducted by Khalil et al. ${ }^{6}$ In our study, $54.3 \%$ students faced 


\section{Menstrual irregularities in female students during online classes}

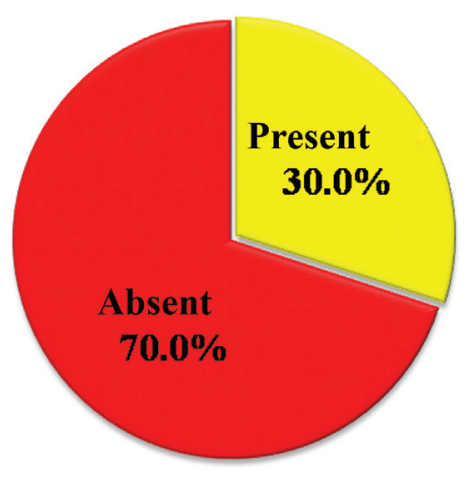

Fig. 1 Menstrual irregularities in female students during online classes.

\section{Aggressive nature in male students during online classes}

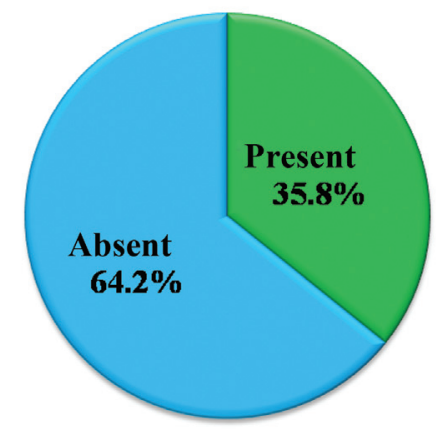

Fig. 2 Aggressive nature in male students during online classes.

visual problems which was also seen in the study conducted by Kaya. ${ }^{7}$ Our study shows that $48.3 \%$ students had sleep disturbance while $45 \%$ students felt loneliness and $50.6 \%$ students experienced frequent headaches during online classes and these results were the same as that of the study conducted by Mridul et al. ${ }^{8}$ In our study, $62.6 \%$ students had weight gain during online classes which was also seen in the study conducted by Rezaeipour. ${ }^{9}$ In our study, $30 \%$ females had menstrual irregularities and $35.8 \%$ students had aggressive behavior.

\section{Conclusion}

From the present study, we can conclude that online classes have a negative impact not only on the mental but also on the physical and social health of Indian medical and dental students. In the study, it is observed that the preferred mode of teaching for most of the students is still offline.

\section{Deviation to alcohol}

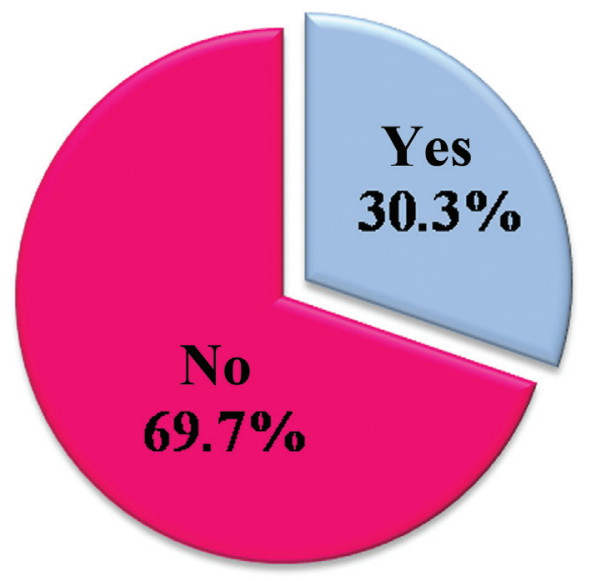

Fig. 3 Deviation to alcohol.

\section{Deviation to smoking}

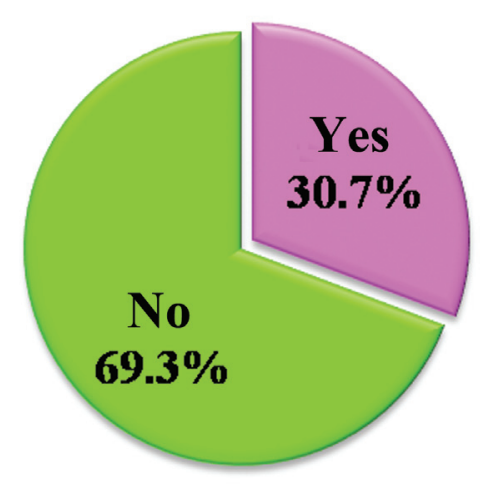

Fig. 4 Deviation to smoking.

Due to this shift toward online classes, students are frustrated because they are not able to study adequately via online teaching. On the one hand, online teaching is a great help in this pandemic to maintain the continuity of education, but, on the other hand, it has been only able to provide theoretical knowledge to students. Medical and dental branches are predominantly ruled by particle work with full clinical exposure. This practical exposure cannot be provided via online teaching. If these budding doctors will not interact with their subjects (cadaver or patient), they will not be able to learn medical science adequately. And this lack of exposure is dragging these students toward frustration, lowering of interest toward their careers. This is not only harmful for the careers of these students but also for the future medical fraternity, as these virtually trained professionals will be the 
future of the medical field. Looking toward impact on the physical health, many students experience frequent headaches, problems in their vision, and disturbance in the sleep cycle. This is due to prolonged screen time and increased exposure to harmful rays. These headaches can be due to a vision problem, or they can be the first step toward migraine. These sleep changes further affect the lifestyle of students lowering their concentration power and increasing frustration. Weight gain was also observed in many students which could be due to a sedentary lifestyle. Weight gain is an important and common risk factor for many non-communicable lifestyle diseases like diabetes, hypertension, atherosclerosis, and many more. In many female students, menstrual irregularities were observed. Menstrual irregularities along with weight gain are ready-made platform for polycystic ovary syndrome which is emerging as the most common lifestyle disease in young women. Weight gain is also affecting the mental health of students. Students start having body image issues which can result in disorders like anorexia nervosa and bulimia nervosa. It was observed that due to the lack of interaction with peer groups and batch mates students feel lonely and aggressive. This loneliness is dragging them toward addiction. Addiction toward alcohol consumption and smoking cigarette is observed in many students. All these parameters like loneliness, frustration, addiction, weight gain, and poor academic performance due to lower concentration are slowly and progressively making these young students prone to depression and other major non-communicable lifestyle diseases. A healthy youth is important for the growth of the nation. In future, if another pandemic wave strikes, we should be ready to combat it, so it is really important to council students and their parents about lifestyle and importance of mental well-being for the a proper career of the students. It is also a necessity to figure out a way to provide practical exposure to students without risking their health.

\section{Funding \\ None.}

Conflict of Interest

None declared.

\section{References}

1 Tanveer Awan M, Bhaumik A, Hassan S, Ul Haq I. Covid-19 pandemic, outbreak educational sector and students online learning in Saudi Arabia. J Entrep Educ 2020;23(03):23

2 Middleton AJ. How effective is distance education? Int J Instr Media 1997;24:133-138 Accessed October 12, 2021 at: https:// eric.ed.gov/?id=EJ569045

3 Park K. Textbook of Preventive and Social Medicine 25th edition. Banarsidas Bhanot Publishers; 2019 chap-2, p.14, ISBN 978-9382219-15-6

4 Williams DE. The future of medical education: flipping the classroom and education technology. Ochsner J 2016;16(01): $14-15$

5 Schwartzstein RM, Roberts DH. Saying goodbye to lectures in medical school-paradigm shift or passing fad? N Engl J Med 2017; 377(07):605-607

6 Khalil R, Mansour AE, Fadda WA, et al. The sudden transition to synchronised online learning during the covid-19 pandemic in Saudi Arabia: a qualitative study exploring medical students perceptive. BMC Med Educ 2020;20:285

7 Kaya $\mathrm{H}$. Investigation of the effect of online education on eye health in covid-19 pandemic. Int J Assessment Tools Educ 2020;7 (03):488-496

8 Bandana BMridul, Sharma D, Kaur N. Online classes during covid19 pandemic: anxiety, stress \& depression among university students. Ind J Forens Med Toxicol 2021;15(01):186-189

9 Rezaeipour M. COVID-19-related weight gain in school-aged children. Int J Endocrinol Metab 2020;19(01):e110634 